\title{
Predominance of CTX-M-type extended-spectrum $\beta$-lactamase genes among enterobacterial isolates from outpatients in Brazil
}

\author{
Luciene A.R. Minarini ${ }^{\mathrm{a}, \mathrm{b}}$, Laurent Poirel ${ }^{\mathrm{a}, *}$, Nathalia A.C. Trevisani ${ }^{\mathrm{b}}$, \\ Ana Lucia C. Darini ${ }^{\mathrm{b}}$, Patrice Nordmann ${ }^{\mathrm{a}}$ \\ aService de Bactériologie-Virologie, INSERM U914 "Emerging Resistance to Antibiotics”, Hôpital de Bicêtre, Assistance Publique/Hôpitaux de Paris, \\ Faculté de Médecine et Université Paris-Sud, K.-Bicêtre, France \\ ${ }^{\mathrm{b}}$ Departamento de Análises Clínicas, Toxicológicas e Bromatológicas, Faculdade de Ciências Farmacêuticas de Ribeirão Preto, \\ Universidade de São Paulo, USP, Ribeirão Preto, SP 14040-903, Brazil
}

Received 4 February 2009; accepted 29 May 2009

\begin{abstract}
Two hundred fifty-seven nalidixic acid-resistant enterobacterial isolates were collected in a Brazilian community from January 2000 to May 2005 to determine the prevalence of plasmid-encoded extended-spectrum $\beta$-lactamases. The bla $a_{\mathrm{CTX}-\mathrm{M}}$ genetic environment was determined by polymerase chain reaction and sequencing. Eleven isolates $(4.2 \%)$ harbored a $b l a_{\mathrm{CTX}-\mathrm{M}-2}$ gene, 3 isolates $b l a_{\mathrm{CTX}-\mathrm{M}-9}, 2$ isolates $b l a_{\mathrm{CTX}-\mathrm{M}-8}$, and 6 isolates $b l a_{\mathrm{SHV}-5}$. Two novel bla $_{\mathrm{CTX}-\mathrm{M}-2}$ variants, namely, bla $_{\mathrm{CTX}-\mathrm{M}-74}$ and bla $_{\mathrm{CTX}-\mathrm{M}-75}$, were identified.
\end{abstract}

(C) 2009 Elsevier Inc. All rights reserved.

Keywords: Extended-spectrum $\beta$-lactamases; CTX-M; Outpatients; Brazil

Since the late 1990s, Enterobacteriaceae producing extended-spectrum $\beta$-lactamases (ESBLs) and, in particular, CTX-M enzymes have emerged in hospital and community settings as important sources of urinary tract infections (UTIs). In Brazil, ESBLs have been predominantly detected in Klebsiella spp. recovered from hospital settings (Cassettari et al., 2009; Minarini et al., 2008; Peirano et al., 2009), effluents of hospital sewages (Prado et al., 2008), exported chicken meats (Warren et al., 2008), and community-onset infections (Minarini et al., 2007). Isolates harboring the $b l a_{\mathrm{SHV}-5}, b l a_{\mathrm{SHV}-11}, b l a_{\mathrm{CTX}-\mathrm{M}-2}$, and $b l a_{\mathrm{CTX}-\mathrm{M}-9}$ genes are the most frequently found (Minarini et al., 2007; Peirano et al., 2009). However, the distribution of ESBL producers among community-onset pathogens in South America remains unknown.

Our study was aimed to evaluate the prevalence of ESBLs among community-onset and quinolone-resistant enterobacterial isolates $(n=257)$ in a city in Southeast Brazil (Juiz de

\footnotetext{
* Corresponding author. Service de Bactériologie-Virologie, Hôpital de Bicêtre 78, rue du Général Leclerc, 94275 Le Kremlin-Bicêtre, France. Tel.: +33-1-45-21-36-24; fax: +33-1-45-21-63-40.

E-mail address: laurent.poirel@bct.aphp.fr (L. Poirel).
}

Fora, State of Minas Gerais) during a 5 1/2-year period from January 2000 to May 2005. ESBL producers were searched among nalidixic acid-resistant isolates since linkage between resistance to quinolone/fluoroquinolone and ESBLs has been often reported (Minarini et al., 2007; Warren et al., 2008).

The antibiotic susceptibility of the enterobacterial isolates was determined by a disk-diffusion technique on MuellerHinton agar plates with $\beta$-lactam (cefoxitin, ceftazidime, and cefotaxime) and non- $\beta$-lactam (acid nalidixic, ciprofloxacin, norfloxacin, ofloxacin, levofloxacin, trimethoprim-sulfamethoxazole, tetracycline, and gentamicin) antibiotic-containing disks according to the Clinical and Laboratory Standards Institute guidelines (CLSI, 2008). ESBL production was confirmed by the combination disk methods using Oxoid disks. Twenty-four (9.3\%) ESBL-producing Enterobacteriaceae strains were detected in a collection of nalidixic acid-resistant enterobacterial isolates recovered from 21 patients. Species distribution for those 24 ESBL-producing isolates was as follows: 9 Escherichia coli, 6 Klebsiella pneumoniae, 5 Enterobacter cloacae, 2 Providencia stuartii, 1 Morganella morganii, and 1 Citrobacter freundii. ESBLpositive isolates were all from UTIs, except one recovered from a wound. 
Fluoroquinolone-resistant isolates harboring an ESBL phenotype were detected in some Brazilian medical centers $(22.9 \%)$ in 2002 and 2003, indicating that these isolates are disseminated across Brazil (Pereira et al., 2007). In our study, isolates were tested for TEM-, SHV-, and CTX-M-type encoding genes, but the most commonly identified ESBLs were CTX-M-type enzymes $(n=18)$, followed by SHV type $(n=6)$. Primers used for polymerase chain reaction (PCR) amplification of $\beta$-lactam resistance genes and for analysis of their genetic environments are reported in Table 1 . Sequencing of blaESBL allowed to identify 18 CTX-Mproducing strains distributed as follows: CTX-M-2-like ( $n=$ $13,72 \%)$, CTX-M-8 $(n=2,11 \%)$, and CTX-M-9 $(n=3$, 17\%). CTX-M-2-like determinants included $b l a_{\mathrm{CTX-M-2}}$ and the 2 novel variants $b l a_{\text {СTX-M-74 }}$ and $b l a_{\text {СтХ-M-75 }}$ (GenBank accession numbers GQ149243 and GQ149244, respectively). CTX-M-74 was from E. cloacae JF216 isolated in 2004 and differed from CTX-M-2 by a single amino acid alteration (Pro to Thr at position 170). CTX-M-75 was from P. stuartii JF29 isolated in 2002 and differed from CTX-M-2 by a single amino acid substitution (Pro to Ser at position 18). The $b l a_{\mathrm{SHV}-5}$ gene was detected in the 6 remaining and bla $_{\mathrm{CTX}-\mathrm{M}}$-negative isolates $(25 \%)$. The high proportion of CTX-M producers found in this study (75\%) is somewhat lower than that reported from other Latin American countries such as Bolivia and Peru (Pallecchi et al., 2007). However, this proportion is higher as compared with North America (Lewis et al., 2007; Pitout et al., 2007). CTX-M-2producing strains were more prevalent in $2004(n=7)$ than in 2000 to 2003 ( 1 isolate per year), which could be related to a significant increase in the number of Enterobacteriaceae isolates producing ESBL in the community.

The genetic environment of the $b l a_{\mathrm{CTX}-\mathrm{M}}$ genes was characterized by PCR and sequencing (Lartigue et al.,
2007). ISEcp 1-like insertion sequences is known to play a role in the mobilization of the $b l a_{\text {СтХ-м }}$ genes by a transcriptional mechanism by recognizing a variety of DNA sequences as right inverted repeat. ISEcpl was identified upstream of all the $b l a_{\text {СтХ-M-9 }}$ genes, its right boundary being located $74 \mathrm{bp}$ upstream of the $\beta$-lactamase gene. ISCR 1 that includes the orf513 transposase gene has been always identified in association with the $b l a_{\text {CTX-M-2-like }}$ genes, including the new alleles $b a_{\mathrm{CTX}} \mathrm{M-74}$ and bla $_{\mathrm{CTX}}$-M75. The distance between the ISCRI element and the bla $_{\mathrm{CTX}-\mathrm{M}-2}$ start codon varied; in 8 isolates $(E$. coli $\mathrm{JF} 25, E$. coli JF26, E. coli JF239, E. coli JF251, E. coli JF286, $P$. stuartii JF29, K. pneumoniae JF230, and M. morganii 89), the distance between the right extremity of ISCRI and the bla $_{\mathrm{CTX-M-2}}$ gene was $266 \mathrm{bp}$. In the $4 E$. cloacae isolates (isolates JF182, JF183, JF207, and JF216) and in the single $P$. stuartii isolate (JF244A), the $b l a_{\text {CTX-M-2 }}$ gene was separated from ISCRI by $260 \mathrm{bp}$. Whereas a $P_{\text {ORI }}$ promoter was identified in the region separating ISCR1 from the $b l a_{\text {CTX-M-2 }}$ gene as previously described by (RodriguezMartinez et al. 2006), a $P_{\mathrm{c}}$ promoter showing a variation in the -35 region (TTTTAC instead of TTATAC) was found in K. pneumoniae JF230. Downstream of the $b l a_{\mathrm{CTX}-\mathrm{M}-2}-\mathrm{like}$ genes, a sequence showing $99 \%$ identity with the downstream-located DNA sequence of the $b l a_{\mathrm{KLUA}-1}$ gene from Kluyvera ascorbata was evidenced. This sequence was followed by a second copy of the $3^{\prime}$-CS belonging to a typical class 1 integron, as reported previously (Valverde et al., 2006). Overall, the genetic environment linked to the $b l a_{\text {CTX-M }}$ genes was variable, showing that the dissemination of those genes in those isolates was not related to a single structure.

Plasmid DNA of enterobacterial isolates was extracted using the Kieser technique (Kieser, 1984). Conjugal transfer

Table 1

Sequences of primers used for detection of ESBL genes and their genetic environment (Lartigue et al., 2007)

\begin{tabular}{|c|c|c|c|}
\hline Primer & Sequence & Location & Accession no. (start-stop) \\
\hline CTX-MA1 & 5'-SCSATGTGCAGYACCAGTAA-3' & $b_{\text {bTX-M }}$ gene & AF488377 (270-813) \\
\hline CTX-MA2 & 5'-CCGCRATATGRTTGGTGGTG-3' & $b l a_{\mathrm{CTX}-\mathrm{M}}$ gene, reverse primer & \\
\hline СТXM2A & 5'-GCCGCTCAATGTTAACGG-3' & CTX-M-2 group & EF592571 (6150-7003) \\
\hline СТXМ2B & 5'-GAAACCGTGGGTTACGAT-3' & CTX-M-2 group, reverse primer & \\
\hline СТXM9A & 5'-CTGATGTAACACGGATTGAC-3' & CTX-M-9 group & AF252622 (1704-2599) \\
\hline TOHO2b rev & 5'-TTACAGCCCTTCGGCGAT-3' & CTX-M-9 group, reverse primer & \\
\hline $\mathrm{TEM} \alpha$ & 5'-GAGTATTCAACATTTCCGTGT-3' & $b l a_{\mathrm{TEM}}$ gene & EU418920 (648-1554) \\
\hline TEM $\beta$ & 5'-TAATCAGTGAGGCACCTATCT-3' & $b l a_{\mathrm{TEM}}$ gene, reverse primer & \\
\hline SHVA & 5'-ATGCGTTATTTCGCCTGTGT-3' & $b l a_{\text {SHV }}$ gene & EU418908 (1-861) \\
\hline SHVB & 5'-TTAGCGTTGCCAGTGCTCG-3' & $b l a_{\mathrm{SHV}}$ gene, reverse primer & \\
\hline CTX825F & 5'-CGCTTTGCCATGTGCAGCACC-3' & $b l a_{\mathrm{CTX}-\mathrm{M}-8}$ gene & AF189721 (475-781) \\
\hline CTX825R & 5'-GCTCAGTACGATCGAGCC-3' & $b l a_{\mathrm{CTX}-\mathrm{M}-8}$ gene, reverse primer & \\
\hline ISEcpPROM+ & 5'-TGCTCTGTGGATAACTTGC-3' & ISEcpl & AF252622 (1520-2599) \\
\hline IS903bint & 5'-GCTTTTTGACTTTCCACTCGC-3 & ÍS903B transposase & \\
\hline M2A3r & 5'-ACCTTACTGGTACTGCACAT-3' & $b l a_{\mathrm{CTX}-\mathrm{M}-2}$ gene, reverse primer & EF592571 (5728-6360) \\
\hline M2A5f & 5'-CCAAATCGAACCTTATTAGAGC-3' & Orf513 & \\
\hline M2A4f & 5'-CACAGTTGGTGACGTGGCTTAA-3' & $b l a_{\mathrm{CTX}-\mathrm{M}-2}$ gene, internal primer & EF592571 (6753-7611) \\
\hline qacED1r & 5'-CCTCCATGATACCGAGTGAGAA-3' & Orf3 & \\
\hline IS903bint & 5'-GCTTTTTGACTTTCCACTCGC-3 & ÍS903B transposase & \\
\hline
\end{tabular}


Table 2

Characteristics of the ESBL-producing isolates, including isolation dates, patient sex, and age

\begin{tabular}{|c|c|c|c|c|c|c|c|c|c|c|c|c|c|c|c|c|c|}
\hline \multirow[t]{2}{*}{ Isolates } & \multirow{2}{*}{$\begin{array}{l}\text { Isolation date } \\
\text { (month/day/year) }\end{array}$} & \multirow{2}{*}{$\begin{array}{l}\text { Patient } \\
\text { age } \\
\text { (years) }\end{array}$} & \multirow[t]{2}{*}{ Sex } & \multirow[t]{2}{*}{ ESBL type } & \multicolumn{8}{|c|}{ MIC values $(\mu \mathrm{g} / \mathrm{mL})$} & \multirow[t]{2}{*}{ Coresistance phenotype } & \multirow{2}{*}{$\begin{array}{l}\text { Transfer } \\
\text { in } E \text {. coli } \\
\text { recipients }\end{array}$} & \multirow{2}{*}{$\begin{array}{l}\text { Coresistance } \\
\text { transferred with } \\
\text { bla }_{\text {CTX-M genes }}\end{array}$} & \multirow{2}{*}{$\begin{array}{l}\text { Plasmid } \\
\text { size }(k b)\end{array}$} & \multirow{2}{*}{$\begin{array}{l}\text { PFGE } \\
\text { type }\end{array}$} \\
\hline & & & & & FOX & $\mathrm{CAZ}$ & CTX & NAL & CIP & NOR & OFL & LVX & & & & & \\
\hline E. cloacae JF182 & $6 / 8 / 2004$ & 90 & M & CTX-M-2 & $>128$ & 64 & $>128$ & $>128$ & 32 & 64 & 16 & 8 & NAL, CIP, SXT, TET & Transf. & TET & 154 & A \\
\hline E. cloacae JF183 & $6 / 11 / 2004$ & 68 & $\mathrm{~F}$ & CTX-M-2 & $>128$ & 32 & $>128$ & $>128$ & 64 & $>128$ & 32 & 32 & NAL, CIP, GEN, SXT, TET & Conj. & SXT & 154 & $\mathrm{~B}$ \\
\hline E. cloacae JF207 & $8 / 11 / 2004$ & 82 & $\mathrm{~F}$ & CTX-M-2 & $>128$ & 64 & $>128$ & $>128$ & 64 & $>128$ & 64 & 64 & NAL, CIP, SXT, TET & Transf. & SXT & 48 & $\mathrm{C}$ \\
\hline E. coli JF239 & $10 / 23 / 2004$ & 35 & $\mathrm{~F}$ & CTX-M-2 & 8 & 4 & 128 & $>128$ & 128 & 128 & 32 & 32 & NAL, CIP, GEN, SXT, TET & Transf. & TET & 154 & $\mathrm{H}$ \\
\hline E. coli JF25 & $11 / 3 / 2001$ & 64 & $\mathrm{M}$ & CTX-M-2 & 16 & 16 & $>128$ & $>128$ & 16 & 32 & 16 & 8 & NAL, CIP, SXT, TET & Transf. & TET & 154 & I \\
\hline E. coli JF251 & $11 / 16 / 2004$ & 50 & $\mathrm{~F}$ & CTX-M-2 & 4 & 4 & $>128$ & $>128$ & 8 & 16 & 16 & 8 & NAL, CIP, GEN, SXT, TET & Transf. & GEN & 154 & $\mathrm{~J}$ \\
\hline E. coli JF26 & $4 / 2 / 2002$ & 47 & $\mathrm{~F}$ & CTX-M-2 & 8 & 8 & $>128$ & $>128$ & 8 & 32 & 16 & 8 & NAL, CIP, TET & Transf. & None & 114 & $\mathrm{~L}$ \\
\hline E. coli JF286 & $1 / 24 / 2005$ & 65 & $\mathrm{~F}$ & CTX-M-2 & 32 & 8 & 128 & $>128$ & 64 & 128 & 128 & 64 & NAL, CIP, GEN, SXT, TET & Transf. & None & 154 & $\mathrm{~N}$ \\
\hline K. pneumoniae JF230 & $10 / 4 / 2004$ & 73 & M & CTX-M-2 & 4 & 16 & 128 & $>128$ & 16 & 64 & 32 & 16 & NAL, CIP, SXT & Transf. & SXT & 114 & $\mathrm{~S}$ \\
\hline M. morganii JF89 & $12 / 26 / 2003$ & 49 & $\mathrm{~F}$ & CTX-M-2 & $>128$ & 8 & 128 & $>128$ & 64 & 64 & 128 & 64 & NAL, CIP, GEN, SXT & Transf. & GEN & 48 & ND \\
\hline P. stuartii JF244 & $10 / 30 / 2004$ & 88 & M & CTX-M-2 & 4 & 16 & 128 & $>128$ & 64 & 128 & 64 & 128 & NAL, CIP, GEN, SXT, TET & Transf. & GEN & 154 & ND \\
\hline E. coli JF 213 & $8 / 25 / 2004$ & 55 & $\mathrm{~F}$ & CTX-M-8 & 4 & $<1$ & 8 & $>128$ & 4 & 8 & 8 & 4 & NAL, CIP, SXT, TET & Transf. & None & 114 & F \\
\hline E. coli JF74 & $11 / 27 / 2003$ & 60 & $\mathrm{~F}$ & CTX-M-8 & 8 & 128 & 16 & $>128$ & 0.12 & 0.5 & 0.5 & 1 & NAL, SXT, TET & Transf. & None & 114 & F \\
\hline C. freundii JF130 & $3 / 22 / 2004$ & 88 & $\mathrm{~F}$ & СТХ-M-9 & 128 & $>128$ & 8 & $>128$ & 32 & 64 & 64 & 32 & NAL, CIP, SXT, TET & Transf. & TET & 114 & ND \\
\hline E. coli JF301 & $2 / 1 / 2005$ & 80 & $\mathrm{~F}$ & CTX-M-9 & 32 & 16 & $>128$ & $>128$ & 32 & 32 & 16 & 8 & NAL, CIP, GEN & Transf. & None & 114 & $\mathrm{O}$ \\
\hline K. pneumoniae JF17 & $4 / 10 / 2002$ & 8 & $\mathrm{~F}$ & CTX-M-9 & 32 & 8 & 64 & $>128$ & 4 & 8 & 8 & 2 & NAL, CIP, GEN, SXT, TET & Transf. & TET & 114 & Q \\
\hline E. cloacae JF216 & $9 / 2 / 2004$ & 82 & $\mathrm{~F}$ & CTX-M-74 & $>128$ & $>128$ & $>128$ & $>128$ & 16 & 64 & 16 & 8 & NAL, CIP, SXT, TET & Conj. & SXT, TET & 48 & $\mathrm{D}$ \\
\hline P. stuartii JF29 & $2 / 11 / 2002$ & 48 & $\mathrm{~F}$ & CTX-M-75 & 32 & $<1$ & 32 & $>128$ & 32 & $>128$ & 16 & 16 & NAL, CIP, GEN, SXT, TET & Transf. & GEN, TET & 180 & ND \\
\hline E. cloacae JF277 & $1 / 11 / 2005$ & 51 & M & SHV-5 & $>128$ & 128 & 32 & 32 & 0.5 & 1 & 1 & 0.5 & NAL, GEN & Conj. & GEN & 60 & E \\
\hline E. coli JF220 & 9/15/2004 & 2 & $\mathrm{~F}$ & SHV-5 & 32 & 32 & 8 & 16 & $<0.03$ & $<0.03$ & 0.06 & $<0.03$ & NAL, SXT & Conj. & SXT & 48 & $\mathrm{G}$ \\
\hline K. pneumoniae JF10 & $11 / 6 / 2001$ & 40 & $\mathrm{~F}$ & SHV-5 & 4 & $>128$ & 16 & $>128$ & 4 & 16 & 4 & 4 & NAL, SXT, GEN & ND & ND & ND & $\mathrm{P}$ \\
\hline K. pneumoniae JF6 & $7 / 14 / 2001$ & 29 & M & SHV-5 & 8 & $>128$ & 16 & $>128$ & 8 & 64 & 16 & 8 & NAL, GEN & ND & ND & ND & $\mathrm{R}$ \\
\hline K. pneumoniae JF7 & $8 / 28 / 2001$ & 47 & $\mathrm{~F}$ & SHV-5 & 8 & 128 & 16 & $>128$ & 8 & 32 & 8 & 8 & NAL, GEN & ND & ND & ND & $\mathrm{R}$ \\
\hline K. pneumoniae JF16 & $3 / 15 / 2002$ & 37 & M & SHV-5 & 8 & $>128$ & 32 & $>128$ & 4 & 16 & 4 & 4 & NAL, GEN & ND & ND & ND & $\mathrm{R}$ \\
\hline
\end{tabular}

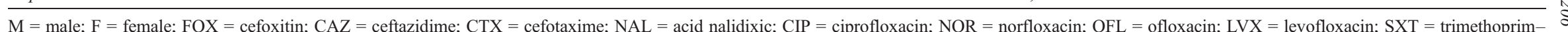
sulfamethoxazole; TET = tetracycline; GEN = gentamicin; Transf. = transfer by electroporation to E. coli TOP10; Conj. = transfer by conjugation to $E$. coli $\mathrm{J} 53 \mathrm{Azi}{ }^{\mathrm{R}}$; ND = not determined. 
of CTX-M determinants was performed in liquid culture media using an azide-resistant $E$. coli $\mathrm{J} 53\left(\mathrm{Azi}^{\mathrm{R}}\right)$ as recipient strain, and transformation of nonconjugative $b l a_{\mathrm{CTX}-\mathrm{M}^{-}}$ harboring plasmids was carried out by electroporation into E. coli TOP10. Plasmid DNAs of these transformants were extracted using the Kieser technique, and their size was estimated by comparison with reference plasmid DNAs of E. coli 50192 (Girlich et al., 2007). Hybridization experiments were performed after a Southern transfer from an agarose gel containing plasmid DNA of E. coli TOP10 electroporants and original $b l a_{\mathrm{CTX}-\mathrm{M}}$-positive strains. Plasmids harboring $b l a_{\mathrm{CTX}-\mathrm{M}}$ genes ranged from 48 to $180 \mathrm{~kb}$ in size. Of the 18 bla $_{\mathrm{CTX}-\mathrm{M}}$-positive isolates, plasmid conjugation was obtained for only 2 (E. cloacae JF216 and JF183), with plasmids of different sizes (48 and $154 \mathrm{~kb}$, respectively). The 16 other $b l a_{\mathrm{CTX}-\mathrm{M}}$-positive plasmids were not self-transferable, although high molecular weight plasmids were visualized in donor strains by hybridization (data not shown) (Table 2).

The spread of bla $a_{\mathrm{CTX}-\mathrm{M}}$-positive $E$. coli and $K$. pneumoniae isolates was not related to the spread of a single clone as reported in several studies focusing on community-onset infections (Ho et al., 2007; Lartigue et al., 2007), therefore, suggesting the dissemination of

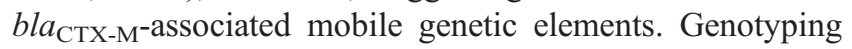
performed by pulsed-field gel electrophoresis (PFGE) (Gauton, 1997; Tenover et al., 1995) identified 16 PFGE types, of which 14 were unique and 2 ( $\mathrm{F}$ and $\mathrm{R}$ types) included more than 1 isolate (Table 2). Nine pulsotypes were identified for $E$. coli, 5 for $E$. cloacae, and 4 for K. pneumoniae. The isolates harboring CTX-M-2- and CTX-M-9-type determinants had distinct PFGE profiles, whereas 3 of the $4 \mathrm{~K}$. pneumoniae isolates harboring the $b_{\text {la }} a_{\mathrm{SH}-5}$ gene and recovered from different patients corresponded to a single clone (type R).

Two E. coli isolates harboring the $b l a_{\text {CTX-M-8 gene }}$ identified among Brazilian isolates in 1997 (Bonnet et al., 2000) were also identified with the same PFGE profile, although they had been isolated from different patients.

This study provides additional information regarding the molecular epidemiology of plasmid-encoded ESBL determinants among enterobacterial isolates circulating in Brazilian community settings. The prevalence $(9.3 \%)$ of ESBL producers among quinolone-resistant enterobacterial isolates mostly recovered from UTIs is high, considering the large diversity of bacterial species, enzymes, and genotypes circulating in the community. The finding of 2 novel variants, bla $a_{\mathrm{CTX}-\mathrm{M}-74}$ and bla $_{\mathrm{CTX-M-75}}$, differing by single nucleotide substitutions from the most prevalent $b l a_{\mathrm{CTX}-\mathrm{M}}$ gene $\left(\right.$ bla $\left._{\mathrm{CTX}-\mathrm{M}-2}\right)$ detected in Brazil suggests a local evolution of those resistance determinants.

\section{Acknowledgments}

The authors are grateful to the Lemos Laboratórios de Análises Clínicas for supplying the isolates. This work was supported by grants from Fundação de Amparo à Pesquisa do Estado de São Paulo (FAPESP 2006/55456-5), by grants from the Ministère de l'Education Nationale et de la Recherche Université Paris XI, France, by grants from the European Community (DRESP2, LSHM-CT-2005-018705 and TROCAR contract HEALTH-F3-2008-223031), and by the INSERM, France. L.A.R.M. received a fellowship from Coordenação de Aperfeiçoamento de Pessoal de Nível Superior-CAPES (Brazil).

\section{References}

Bonnet R, Sampaio JLM, Labia R, De Champs C, Sirot D, Chanal C, Sirot J (2000) A novel CTX-M $\beta$-lactamase (CTX-M-8) in cefotaxime-resistant Enterobacteriaceae isolated in Brazil. Antimicrob Agents Chemother 44:1936-1942.

Cassettari VC, da Silveira IR, Dropa M, Lincopan N, Mamizuka EM, Matté MH, Matté GR, Menezes PR (2009) Risk factors for colonisation of newborn infants during an outbreak of extended-spectrum $\beta$-lactamaseproducing Klebsiella pneumoniae in an intermediate-risk neonatal unit. J Hosp Infect 71:340-347.

Clinical and Laboratory Standards Institute (CLSI) (2008) Performance standards for antimicrobial susceptibility testing: 18th informational supplement (M100-S18). Baltimore, MD, USA: CLSI.

Gauton RK (1997) Rapid pulsed-field gel electrophoresis protocol for typing of Escherichia coli O157:H7 and other Gram-negative organisms in 1 day. J Clin Microbiol 34:2448-2453.

Girlich D, Poirel L, Carattoli A, Kempf I, Lartigue MF, Bertini A, Nordmann $\mathrm{P}$ (2007) Extended-spectrum $\beta$-lactamase in Escherichia coli in France. Appl Environ Microbiol 73:4681-4685.

Ho PL, Poon WWN, Loke SL, Leung MST, Chow KH, Wong RCW, Yip KS, Lai EL, Tsang KWT, on behalf of the COMBAT study group (2007) Community emergence of CTX-M type extended-spectrum $\beta$-lactamases among urinary Escherichia coli from women. J Antimicrob Chemother 60:140-144.

Kieser T (1984) Factors affecting the isolation of CCC DNA from Streptomyces lividans and Escherichia coli. Plasmid 12:19-36.

Lartigue MF, Zinsius C, Wenger A, Bille J, Poirel L, Nordmann P (2007) Extended-spectrum $\beta$-lactamases of the CTX-M type now in Switzerland. Antimicrob Agents Chemother 51:2855-2860.

Lewis II JS, Herrera M, Wickes B, Patterson JE, Jorgensen JH (2007) First report of the emergence of CTX-M-type extendedspectrum $\beta$-lactamases (ESBLs) as the predominant ESBL isolated in a U.S. health care system. Antimicrob Agents Chemother 51: 4015-4021.

Minarini LAR, Gales AC, Palazzo ICV, Darini ALC (2007) Prevalence of community-occurring extended-spectrum $\beta$-lactamase producing Enterobacteriaceae in Brazil. Curr Microbiol 54:335-341.

Minarini LAR, Clímaco EC, Guimarães DB, Ferreira JC, Palazzo IC, Martinez R, Darini AL (2008) Clonal transmission of ESBL-producing Klebsiella spp. at a university hospital in Brazil. Curr Microbiol 56:587-591.

Pallecchi L, Bartoloni A, Fiorelli C, Mantella A, Di Maggio T, Gamboa H, Gotuzzo E, Kronvall G, Paradisi F, Rossolini GM (2007) Rapid dissemination and diversity of CTX-M extended-spectrum $\beta$-lactamase genes in commensal Escherichia coli isolates from healthy children from low-resource settings in Latin America. Antimicrob Agents Chemother 51:2720-2725.

Peirano G, Seki LM, Val Passos VL, Pinto MC, Guerra LR, Asensi MD (2009) Carbapenem-hydrolysing $\beta$-lactamase KPC-2 in Klebsiella pneumoniae isolated in Rio de Janeiro, Brazil. J Antimicrob Chemother 63:265-268.

Pereira AS, Andrade SS, Monteiro J, Sader H, Pignatari ACC, Gales AC (2007) Evaluation of the susceptibility profiles, genetic similarity and 
presence of $q n r$ gene in Escherichia coli resistant to ciprofloxacin isolated in Brazilian hospitals. Braz J Infect Dis 11:40-43.

Pitout JDD, Church DL, Gregson DB, Chow BL, McCracken M, Mulvey MR, Laupland KB (2007) Molecular epidemiology of CTX-M-producing Escherichia coli in the Calgary Health Region: emergence of CTX-M-15producing isolates. Antimicrob Agents Chemother 51:1281-1286.

Prado T, Pereira WC, Silva DM, Seki LM, Carvalho AP, Asensi MD (2008) Detection of extended-spectrum $\beta$-lactamase-producing Klebsiella pneumoniae in effluents and sludge of a hospital sewage treatment plant. Lett Appl Microbiol 46:136-141.

Rodriguez-Martinez JM, Poirel L, Canton R, Nordmann P (2006) Common region CR1 for expression of antibiotic resistance genes. Antimicrob Agents Chemother 50:2544-2546.
Tenover FC, Arbeit RD, Doering RV, Mickelsen PA, Murray BE, Persing DH, Swaminathan B (1995) Interpreting chromosomal DNA restriction patterns produced by pulsed-field gel electrophoresis: criteria for bacterial strain typing. J Clin Microbiol 33:2233-2239.

Valverde A, Cantón R, Galán JC, Nordmann P, Baquero F, Coque TM (2006) In117, an unusual In0-like class 1 integron containing CR1 and bla $_{\mathrm{CTX} \text {-M-2 }}$ and associated with a Tn21-like element. Antimicrob Agents Chemother 50:799-802.

Warren RE, Ensor VM, O'Neill P, Butler V, Taylor J, Nye K, Harvey M, Livermore DM, Woodford N, Hawkey PM (2008) Imported chicken meat as a potential source of quinolone-resistant Escherichia coli producing extended-spectrum $\beta$-lactamases in the UK. J Antimicrob Chemother 61:504-508 